\title{
Jurnal Penelitian Perawat Profesional
}

Volume 2 Nomor 1, Februari 2020

e-ISSN 2715-6885; p-ISSN 2714-9757

http://jurnal.globalhealthsciencegroup.com/index.php/JPPP

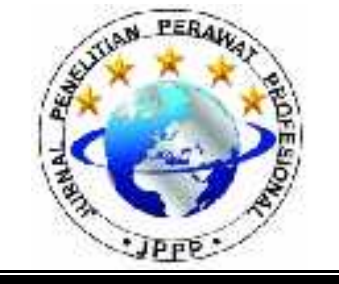

\section{Penentuan Status Maya Index Larva Aedes Sp.}

\author{
Fatimah Azzahra ${ }^{1}$, Emantis Rosa ${ }^{2}$, Muhammad Galih Irianto ${ }^{3}$, Hanna Mutiara ${ }^{2}$ \\ ${ }^{1}$ Fakultas Kedokteran, Universitas Lampung, Jl. Prof. Dr. Ir. Sumantri Brojonegoro No.1, Gedong Meneng, \\ Kec. Rajabasa, Kota Bandar Lampung, Lampung, Indonesia 35145 \\ ${ }^{2}$ Departemen Parasitologi, Fakultas Kedokteran, Universitas Lampung, Jl. Prof. Dr. Ir. Sumantri Brojonegoro \\ No.1, Gedong Meneng, Kec. Rajabasa, Kota Bandar Lampung, Lampung, Indonesia 35145 \\ ${ }^{3}$ Departemen Forensik, Fakultas Kedokteran, Universitas Lampung, Jl. Prof. Dr. Ir. Sumantri Brojonegoro \\ No.1, Gedong Meneng, Kec. Rajabasa, Kota Bandar Lampung, Lampung, Indonesia 35145 \\ *1fatimahazzahra.fa@gmail.com (+6282288902543)
}

\begin{abstract}
ABSTRAK
Demam berdarah atau DBD adalah penyakit yang ditularkan melalui vektor nyamuk Aedes aegypti dan Aedes albopictus. Maya Index dapat digunakan untukmengidentifikasi suatu area yang memiliki risiko tinggi sebagai tempat perkembangbiakan atau breeding site nyamuk Aedes sp. didasarkan pada status kebersihan lingkungan dan ketersediaan tempat-tempat yang berpotensi sebagai tempat perkembangbiakan nyamuk. Tujuan penelitian ini adalah untuk mengetahui status Maya Index, mengidentifikasi tipe tempat penampungan air atau TPA, dan mengidentifikasi jenis larva Aedes sp. yang ditemukandi kecamatan Sukabumi yang dilakukan pada bulan November-Desember 2019. Penelitian ini dilakukan dengan cara survey ke 100 rumah masyarakat di 3 kelurahan, yaitu kelurahan Nusantara, kelurahan Sukabumi dan Kelurahan Sukabumi Indah. Analisis Maya Index menggunakan Breeding Risk Index atau BRI and Hygiene Risk Indexatau HRI. Hasil dari penelitian ini menunjukkan bahwa TPA terkontrol yang paling berpotensi untuk perkembangbiakan nyamuk adalah tempat penampungan air pada dispenser, sedangan TPA tidak terkontrol yang paling berpotensi untuk perkembangbiakan nyamuk adalah kaleng bekas. Ada 2 tipe dari larva nyamuk yang ditemukan, yaitu Aedes aegypti dengan persentase $73.5 \%$ dan Aedes albopictus dengan persentase $26.5 \%$. Status Maya Index dikategorikan kepada kategori sedang yang ditentukan bedasarkan kategoriBreeding Risk Index dan Hygiene risk index. Namun demikian, hal itu tidak berarti daerah tersebut bebas dari kasus DBD. Pengaturan dari masyarakat sangat dibutuhkan untuk mengeradikasi TPA yang memiliki potensial tinggi sebagai tempat perkembangbiakan vektor DBD.
\end{abstract}

Kata Kunci: demam berdarah, larva aedes sp., maya index

\section{DETERMINATION THE MAYA INDEX STATUS OF AEDES SP. LARVAE}

\section{ABSTRACT}

Dengue Fever is a disease that is transmitted through the Aedes aegypti and Aedes albopictus mosquito vectors. Maya Index can be used to identify an area that has a high risk of breeding site of the Aedes sp. Mosquito based on the status of environmental hygiene and the availability of potential places of mosquito breeding. The aim of this study was to determine the type of landfill which has the potential as a breeding ground for mosquitoes, to find out the larvae found in various landfill sites, and to know the Maya index status in Sukabumi District which was carried out in November-December 2019. This research conducted by a direct survey of 100 houses in 3 villages in Sukabumi District, namely Nusantara, Sekabumi, and Sukabumi Indah. Data analysis to 
determine Maya Index uses the Breeding Risk Index or BRI and Hygiene risk index or HRI. The results indicated that the type of controlled water reservoir that had the most potential as a breeding place for mosquitoes was a water reservoir of dispenser, while the type of water reservoir that was not controlled which had the potential as a place for mosquito breeding was a used cans. There were 2 types of larvae found, namely, Aedes aegypti larvae with a percentage of $73.5 \%$ and Aedes albopictus larvae with a percentage of $26.5 \%$. The Maya index status detected there, was a medium category, which obtained from the Breeding Risk Index category and Hygiene Risk Index category. Besides, it did not mean that the area has been free from dengue cases. The role of the community is still very much needed in eradicating landfills which has the potential as a breeding place for dengue mosquitoes vector.

Keyword: dengue fever, larva of aedes sp., maya index

\section{PENDAHULUAN}

Demam Berdarah Dengueatau DBD adalah penyakit yang disebabkan oleh virus Dengue. Penyakit DBD ditularkan melalui gigitan nyamuk yang berasal dari genus Aedes(Kemenkes, 2016). Penderita DBD yang dilaporkan di Indonesia pada tahun 2018 adalah sebanyak 53.075 kasus dengan jumlah kematian sebanyak 344 jiwa. Angka kejadian atau Incidence Rate atau IR 20.01 per 100.000 penduduk dan angka kematian atau Case Fatality Rate atau CFR sebanyak $0.65 \%$ (Kemenkes, 2018). Jumlah kasus DBD di Provinsi Lampung sebesar 6.022 kasus dengan angka kejadian atau insidens rate DBD sebesar 74.86 per 100.000 penduduk pada tahun 2016. Target Renstra Dinas Kesehatan Provinsi Lampung untuk angka kejadian DBD tahun 2015 adalah $<5$ per 100.000 penduduk. Dengan demikian, dapat diartikan bahwa target tersebut belum tercapai (Dinkes, 2016).

Kecamatan Sukabumi merupakan salah satu daerah dengan kasus DBD yang tinggi di kota Bandar Lampung, yaitu sebanyak 67 kasus di tahun 2018 (Dinkes, 2019).Beberapa tahun terakhir kasus DBD di kota Bandar Lampung cenderung fluktuatif, untuk itu perlu dilakukan kewaspadaan dini dalam upaya penanganan yang efektif untuk mencegah penularan penyakit DBD pada masyarakat oleh instansi terkait khususnya Dinas Kesehatan. Salah satu cara yang dapat dilakukan dalam upaya membantu penanggulangan kasus DBD yaitu dengan melakukan analisis tempat perindukan yang berisiko tinggi melalui analisis Maya Index.

Maya Index digunakan untuk mengidentifikasi suatu area yang memiliki risiko tinggi sebagai tempat perkembangbiakan (breeding site) nyamuk Aedes sp. didasarkan pada status kebersihan lingkungan dan ketersediaan tempat-tempat yang berpotensi sebagai tempat perkembangbiakan nyamuk (Satoto, 2005).

Penelitian ini penting dilakukan karena sampai saat ini belum diperoleh informasi terkait Maya Index di kecamatan Sukabumi kota Bandar Lampung serta angka kejadian dari DBD di kota Bandar Lampungmasih berada di bawah target. Dengan diketahuinya Maya Index suatu daerah, diharapkan dapat memberikan informasi yang tepat dan akurat dalam upaya penanggulangan kasus DBD.

\section{METODE}

Jenis dan rancangan penelitian ini adalah observasional analitik dengan pendekatan 
case control untuk menilai status Maya Index larva Aedes sp. di Kecamatan Sukabumi kota Bandar Lampung. Penelitian ini dilaksanakan pada bulan November sampai dengan Desember 2019. Pengambilan sampel dilaksanakan di Kecamatan Sukabumi, Kota Bandar Lampung, Provinsi Lampung dan identifikasi larva dilaksanakan di Laboratorium Mikrobiologi dan Parasitologi Jurusan Pendidikan Dokter Fakultas Kedokteran Universitas Lampung. Penelitian ini menggunakan metode survei pada daerah endemis demam berdarah diKecamatan Sukabumi.

Metode pengambilan sampel yang digunakan dalam penelitian ini adalah purposive sampling, yaitu rumah-rumah yang dijadikan sampel berdasarkan rumah yang pernah ada penderita DBD dan sekitar rumah dengan jarak maksimal 100 meter dari rumah penderita tersebut. Data dianalisis nilai Breeding Risk Index, Hygiene Risk Index, dan ditentukan standar deviasinya menggunakan program Microsoft Excel 010.

Kriteria inklusi sampel kasus adalah bersedia menjadi subjek penelitian dan terdapat satu atau lebih anggota keluarga yang positif DBD berdasarkan laporan surveylans Puskesmas Kecamatan Sukabumi bulan Januari - Desember tahun 2018 dan di bulan Januari hingga November tahun 2019.

Kriteria inklusi sampel kontrol adalah bersedia menjadi subjek penelitiandan bertempat tinggal di lingkungan yang sama dalam radius \pm 100 meter dari tempat tinggal kelompok kasus. Kriteria eksklusi sampel adalah subjek penelitian yang terdapat kasus DBD dan menjadi patokan untuk pemeriksaan jentik pindah dari daerah yang diteliti saat akan dilakukan pengambilan data oleh peneliti.

Hasil penelitian menjelaskan mengenai jenis tempat penampungan air dan larva nyamuk yang ditemukan pada berbagai tempat penampungan air baik yang masih terkontrol ataupun tidak terkontrol serta kategori maya index yang didasarkan pada index BRI (Breeding Risk Index) dan HRI (Hygiene Risk Index). Padamasing-masing jenis tempat penampungan air yang ditemukan positif larva diambil sampel larvanya untuk diidentifikasi. Analisis data menggunakan program Ms. Excel 2010 dengan cara mengkombinasikan 2 index yaitu Breeding Risk Index (BRI) dan Hygiene Risk Index(HRI) yang nantinya dikategorikan menjadi rendah, sedang dan tinggi dengan menggunakan perhitungan distribusi tertinggi (Supartha, 2008).

Breeding Risk Index yang rendah menunjukkan bahwa hanya terdapat sedikit contralable sites dan memiliki resiko rendah untuk terjadi perkembangbiakan larva dan begitu pula sebaliknya. Hygiene Risk Index yang rendah menunjukkan bahwa terdapat sedikit jumlah disposable sites yang termasuk dalam kategori kotor. Nilai BRI dan HRI di setiap rumah disusun dalam matriks $3 \times 3$ untuk menentukan kategori maya index rendah, sedang dan tinggi (Supartha, 2008).

\section{HASIL}

Keadaan TPA yang berpotensi sebagai Tempat Perindukan Nyamuk di Kecamatan Sukabumi

Hasil survei mengenai jenis tempat penampungan air atau kontainerterkontrol yang dapat berpotensi sebagai tempat perkembangbiakan nyamuk dan jumlah 
tempat penampungan air yang ditemukan $\quad$ larva disajikan pada tabel 1.

Tabel 1.

Jenis Kontainer Terkontrol dan Keberadaan Larva Aedes sp. pada 100 rumah warga

\begin{tabular}{|c|c|}
\hline Jenis Kontainer Terkontrol & 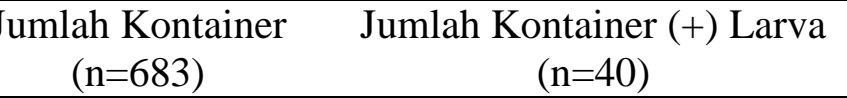 \\
\hline Ember & 438 \\
\hline Penampung air pada dispenser & 15 \\
\hline Wadah minum burung & 50 \\
\hline Bak mandi & 32 \\
\hline Wadah minum ayam & 17 \\
\hline Gentong & 16 \\
\hline Dirigen & 14 \\
\hline Akuarium & 12 \\
\hline Drum & 11 \\
\hline Kolam ikan & 10 \\
\hline Wadah penampung air & 9 \\
\hline Gucci tempat galon & 3 \\
\hline Kendi & 2 \\
\hline $\begin{array}{l}\text { Keterangan : } \\
(-) \text { Kontainer terkontrol yang tidak } \\
\text { ditemukan larva } \\
\text { (+) Kontainer terkontrol yang ditemukan } \\
\text { larva }\end{array}$ & $\begin{array}{l}\text { sebagai tempat perkembangbiakan } \\
\text { nyamuk dan jumlah tempat penampungan } \\
\text { air yang ditemukan larva disajikan pada } \\
\text { tabel } 2 \text {. }\end{array}$ \\
\hline $\begin{array}{l}\text { Tabel 1., dapat diartikan bahwa kontainer } \\
\text { terkontrol yang paling banyak ditemukan } \\
\text { adalah ember dan dispenser, sedangkan } \\
\text { yang paling sedikit adalah kendi. } \\
\text { Kontainer terkontrol yang paling banyak } \\
\text { dijumpai adanya larva adalah dispenser, } \\
\text { sedangkan pada wadah minum ayam, } \\
\text { dirigen, akuarium, kolam ikan, gucci } \\
\text { tempat galon, dan kendi tidak ditemukan } \\
\text { adanya larva. Hasil survei mengenai jenis } \\
\text { tempat penampungan air (TPA)/kontainer } \\
\text { tidak terkontrol yang dapat berpotensi }\end{array}$ & $\begin{array}{l}\text { Tabel 2. dapat diartikan bahwa kontainer } \\
\text { tidak terkontrol yang paling banyak } \\
\text { ditemukan adalah kaleng bekas, } \\
\text { sedangkan yang paling sedikit ditemukan } \\
\text { adalah kloset bekas dan dirigen bekas. } \\
\text { Kontainer tidak terkontrol dengan jenis } \\
\text { kaleng bekas merupakan kontainer yang } \\
\text { paling banyak ditemukan positif larva. } \\
\text { Sedangkan ban bekas, akuarium bekas, } \\
\text { kandang bekas, kendi bekas, dan kloset } \\
\text { bekas tidak ditemukan adanya larva. }\end{array}$ \\
\hline
\end{tabular}


Tabel 2.

Jenis Kontainer Tidak Terkontrol dan Keberadaan Larva Aedes sp. pada 100 rumah warga

\begin{tabular}{lcc} 
Jenis Kontainer Tidak Terkontrol & $\begin{array}{c}\text { Jumlah Kontainer } \\
(\mathrm{n}=247)\end{array}$ & $\begin{array}{c}\text { Jumlah Kontainer (+) Larva } \\
(\mathrm{n}=42)\end{array}$ \\
\hline Kaleng bekas & 82 & 12 \\
Rongsokan & 45 & 4 \\
Ember bekas & 33 & 2 \\
Pot bekas & 29 & 8 \\
Wadah penampung hujan & 13 & 4 \\
Bak mandi bekas & 12 & 4 \\
Ban bekas & 10 & - \\
Akuarium bekas & 5 & - \\
Drum bekas & 5 & 3 \\
Kandang bekas & 3 & - \\
Kendi bekas & 3 & - \\
Kolam ikan bekas & 2 & 2 \\
Tempayan & 2 & 2 \\
Dirigen bekas & 2 & - \\
Kloset bekas & 1 & berpedoman pada buku kunci identifikasi \\
Keterangan : & Aedes jentik dan dewasa di Jawa, Ditjen \\
$(-)$ Kontainer tidak terkontrol yang tidak & PPM \& PLP (1989). Dapat dilihat pada \\
ditemukan larva & tabel 3. berikut yang menunjukan \\
(+) Kontainer tidak terkontrol yang & presentase larva yang didapatkan. Ada \\
ditemukan larva & dua jenis larva nyamuk Aedes sp. yang \\
Identifikasi Larva yang Ditemukan & teridentifikasi, yakni larva nyamuk Aedes \\
Hasil identifikasi larva yang ditemukan & aegypti sebanyak 73.5\% dan larva \\
pada berbagai tempat penampungan air di & nyamuk Aedes albopictus sebanyak \\
Kecamatan & Sukabumi dengan & 26.5\% .
\end{tabular}

Tabel 3.

Persentase larva Aedes sp. yang ditemukan pada kontainer terkontrol dan tidak terkontrol

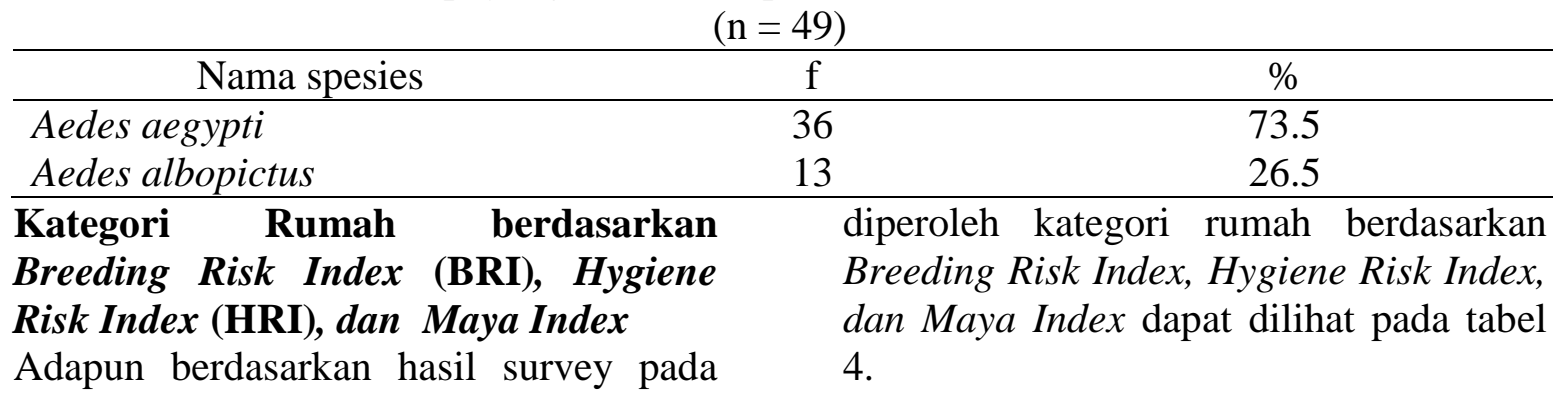

100 rumah di Kecamatan Sukabumi, 
Tabel 4.

Kategori rumah berdasarkan breeding risk index, hygiene risk index, dan maya index

\begin{tabular}{llll}
\hline Keterangan & HRI & BRI & Maya Index \\
\hline Rendah & 0 & 6 & 6 \\
Sedang & 89 & 78 & 70 \\
Tinggi & 11 & 16 & 24 \\
\hline
\end{tabular}

\section{PEMBAHASAN}

Tabel 1. Menunjukkan bahwa kontainer terkontrol yang paling banyak ditemukan dari 13 jenis kontainer adalah ember dan dispenser, sedangkan yang paling sedikit adalah kendi. Hal ini diduga disebabkan karena Kecamatan Sukabumi sedang berada pada peralihan musim kemarau menuju musim hujan, namun hujan masih jarang terjadi. Oleh karena itu, kebanyakan masyarakat lebih memilih ember sebagai tempat penampungan air mereka karena mereka menganggap bahwasannya ember lebih mudah untuk dibersihkan dibandingkan dengan tempat penampungan lainnya. Hal ini sejalan dengan penelitian dari Karnasih (2013), yang menyatakan bahwa kontainer terkontrol yang paling banyak didapatkan pada RW 3 kelurahan Cempaka Putih Barat, Jakarta Pusat adalah ember, yaitu sebanyak 23.3\% dari keseluruhan kontainer yang ditemukan.

Kontainer terkontrol yang paling banyak dijumpai adanya larva adalah dispenser. Di Kecamatan Sukabumi, rata-rata dispenser yang digunakan tidak dibersihkan tempat penampungan air yang berada di bawahnya. Hal ini diduga karena tempat penampungan tersebut tersembunyi sehingga tidak terlalu diperhatikan oleh masyarakat dan mereka sering lupa untuk membuang air pada penampungan tersebut. Hasil data ini didukung dengan penelitian yang telah dilakukan oleh Sari (2017) dimana kontainer terkontrol terbanyak yang positif larva Aedes sp. adalah dispenser, yaitu sebesar 7.2\% (10 buah) dari seluruh kontainer yang ditemukan.

Tabel 2. menjelaskan dari 15 jenis kontainer tidak terkontrol, kontainer dengan jenis kaleng bekas merupakan yang paling banyak ditemukan yaitu sebanyak 82 buah, serta larva yang paling banyak ditemukan juga pada kaleng bekas, yaitu sebanyak 12 kontainer yang positif larva. Hal ini sesuai dengan pernyataan dari Yotopranoto (1998), yang menyebutkan bahwa larva Aedes sp.tidak dapat berkembang biak di tempat yang airnya langsung berhubungan dengan tanah seperti selokan atau kolam, dan pernyataan dari Soegijanto (2004) yang menyebutkan bahwa genangan air yang disukai sebagai tempat perindukan nyamuk Aedes bukan genangan air yang ada di tanah melainkan genangan air yang tertampung di suatu wadah yang biasa disebut kontainer.

Kontainer tidak terkontrol yang paling banyak ditemukan adalah kaleng bekas, sedangkan yang paling sedikit ditemukan adalah kloset bekas dan dirigen bekas. Hal ini diduga karena kebanyakan masyarakat di Kecamatan Sukabumi cenderung mengumpulkan kaleng bekas di luar rumah mereka untuk kembali dijual. Sehingganya, kontainer kaleng bekas yang belum terjual dibarkan menumpuk dan menjadi salah satu kontainer yang berpotensi sebagai tempat perkembangbiakan nyamuk. Hal ini 
sejalan dengan penelitian yang dilakukan oleh Sari (2017), yang berpendapat bahwa kontainer tidakterkontrol yang paling banyak ditemukan di kecamatan Koto Tangah kota Padang adalah kaleng bekas, yaitu sebesar $15 \%$ dari seluruh kontainer yang ditemukan.

Hasil pengamatan dari 100 rumah warga di Kecamatan Sukabumi terdapat 2 jenis larva nyamuk yang teridentifikasi, yaitu larva nyamuk Aedes aegypti dan Aedes albopictus. Aedes aegypti merupakan jenis larva yang paling dominan ditemukan, yaitu dengan persentase sebesar $73.5 \%$. Sedangkan larva nyamuk Aedes albopictus memiliki persentase yang lebih kecil, yaitu 26.5\%. Hal ini sesuai dengan penelitian yang dilakukan oleh Winita (2018), yang menyatakan bahwa Aedes aegypti merupakan vektor utama DBD di Indonesia dan aktivitas kampus yang dilakukan dari pagi hingga sore hari menjadi salah satu faktor risikonya. Pada hasil penelitian Winita (2018) larva yang dominan ditemukan di kampus Salemba Universitas Indonesia adalah larva Aedes aegypti, yakni dari 21 larva yang ditemukan, 17 diantaranya adalah larva Aedes sp.

Ciri-ciri dari larva nyamuk Aedes sp. yaitu memiliki dada yang lebih lebar dari kepalanya. Kepalanya berkembang dengan sepasang antena dan mata majemuk serta sikap mulut yang menonjol. Bagian abdomen larva nyamuk terdiri dari sembilan ruas yang jelas dan ruas ke sepuluh dilengkapi dengan tabung udara (siphon) yang berbentuk silinder. Perbedaan spesies dari nyamuk ini dapat dibedakan dengan melihat bentuk pecten siphon dan sisir pada ruas terakhir (Anies, 2006).
Bentuk sisir pada ruas terakhir pada larva nyamuk Aedes aegypti dan Aedes albopictus menjadi salah satu ciri pembeda dari ke dua nyamuk ini. Sisir pada nyamuk Aedes aegypti memiliki bentuk yang bergerigi tajam di ujungnya. Sedangkan sisir pada larva nyamuk Aedes albopictus berbentuk tumpul pada ujungnya (Anies, 2006).

Tabel 4. memperlihatkan bahwa berdasarkan hasil survey pada 100 rumah di Kecamatan Sukabumi terdapat 6 rumah dengan kategori BRIrendah, 83 rumah dengan kategori BRIsedang, dan 11 rumah dengan kategori BRItinggi. Kemudian berdasarkan HRI, terdapat 87 rumah dengan kategori sedang, 13 rumah dengan kategori tinggi, namun tidak ditemukan adanya rumah yang berkategori rendah. Selanjutnya berdasarkan Maya Index, terdapat 6 rumah dengan kategori rendah, 71 rumah dengan kategori sedang, dan 23 rumah dengan kategori tinggi.

Breeding Risk Index merupakan index yang digunakan untuk menilai status ketersediaan tempat yang dapat berpotensi menjadi tempat perkembangbiakan oleh nyamuk Aedes spp. Nilai BRI didapat dari hasil pembagian jumlah kontainer terkontrol dengan total rata-rata kontainer positif larva. BRI dikategorikan menjadi tiga kategori yakniBRI tinggi dengan rentang 249.26, BRIsedang dengan rentang 49.26-183.99 dan BRIrendah dengan rentang <49.26. Pada gambar 4.5. dapat dilihat kategori BRI rendah memiliki persentase $6 \%$, sedang $78 \%$, dan tinggi $16 \%$. Maka dapat diartikan bahwa nilai BRI di Kecamatan Sukabumi cenderung sedang, yaitu $78 \%$. Hal ini sejalan dengan penelitian yang dilakukan oleh Sona 
(2019), dimana BRI dengan kategori sedang pada 100 rumah di kecamatan Metro Timur yang merupakan salah satu daerah endemis DBD di provinsi Lampung memiliki persentase paling besar, yaitu $57 \%$.

Semakin tinggi nilai BRI disuatu tempat menunjukan bahwa di wilayah tersebut tersedia banyak tempat yang dapat berpotensi menjadi tempat perkembang biakan dari nyamuk Aedes sp. Melihat persentase BRI kategori sedang di Kecamatan Sukabumi yang cukup tinggi maka apabila tidak dilakukan pengontrolan secara berkala pada kontainer di Kecamatan Sukabumi, akan berpotensi terhadap perkembangbiakan nyamuk.

Higiene Risk Index merupakan index kebersihan lingkungan suatu daerah. Nilai HRI dapat diperoleh dari hasil pembagian jumlah kontainer tidak terkontrol dengan total rata-rata kontainer tidak terkontrol positif larva. HRI dikategorikan menjadi tiga kategori yakni HRI rendah dengan rentang <-8.59, HRI sedang dengan rentang -8.59-37.88 dan HRI tinggi dengan rentang 237.88 . Pada gambar 4.6. dapat dilihat kategori HRI rendah memiliki persentase 0\%, sedang 89\%, dan tinggi $11 \%$. Maka dapat diartikan bahwa nilai HRI di Kecamatan Sukabumi cenderung sedang, yaitu $89 \%$. Hal ini sejalan dengan penelitian yang dilakukan oleh Sona (2019), dimana HRI dengan kategori sedang pada 100 rumah di kecamatan Metro Timur yang merupakan salah satu daerah endemis DBD di provinsi Lampung memiliki persentase paling besar, yaitu $95 \%$.

Sesuai dengan pendapat Supartha (2008), HRI yang rendah menunjukkan bahwa terdapat sedikit jumlah kontainer tak terkontrol yang berpotensi sebagai tempat perindukan nyamuk yang termasuk dalam kategori kotor. Menurut Dhewantara (2015), walaupun Hygiene Risk Index (HRI) di suatu daerah masih dalam kategori sedang namun daerah tersebut tetap potensial sebagai tempat perkembangbiakan nyamuk. Melihat persentase HRI kategori sedang di Kecamatan Sukabumi yang cukup tinggi maka apabila tidak dilakukan pengontrolan secara berkala pada kontainer Kecamatan Sukabumi, akan berpotensi terhadap perkembangbiakan nyamuk.

Status Maya Index (MI) berdasarkan kategori Breeding Risk Index (BRI) dan Hygiene Risk Index (HRI) bahwa jumlah rumah yang mempunyai maya index dengan kategori rendah sebesar 6\%, kategori sedang sebesar 70\%, dan kategori tinggi sebesar 24\%. Jadi, dapat diartikan bahwa berdasarkan maya index menunjukkan bahwa rumah di Kecamatan Sukabumi termasuk dalam kategori sedang karena persentase rumah dengan kategori sedang paling besar dibandingkan kategori rendah dan kategori tinggi, yaitu 70\%. Hal ini berarti resiko daerah tersebut dijadikan sebagai tempat perkembangbiakan nyamuk Aedes sp. masih dalam kategori sedang namun bukan berarti sudah bebas dari kasus DBD.

Status maya index yang didapatkan sejalan dengan penelitian yang dilakukan oleh Sona (2019), yang berpendapat bahwa bedasarkan maya index pada 100 rumah di kecamatan Metro Timur termasuk dalam kategori sedang karena persentase rumah dalam kategori sedang paling besar dibandingkan kategori 
lainnya, yaitu 58\%. Penelitian yang dilakukan oleh Prasetywati (2016), juga mengemukakan bahwa hasil analisa maya indeks yang menunjukkan bahwa sebagian besar masyarakat di Jakarta Timur berada dalam tingkat resiko kategori sedang dengan persentase $70.23 \%$.

Dua aspek yang berperan adalah keberadaan habitat perkembangbiakan potensial yang ditunjukkan oleh banyaknya kontainer terkontrol dan sanitasi atau kebersihan lingkungan yang ditunjukkan oleh kontainer tidak terkontrol (Dhewantara, 2015). Bedasarkan data dari Puskesamas Kecamatan Sukabumi, kasus DBD masih tergolong tinggi yaitu terdapat 56 kasus yang tersebar di 3 kelurahan pada tahun 2018. Hal ini menunjukkan bahwa status maya index sedang juga sangat berisiko terhadap penularan DBD apabila masyarakat kurang memperhatikan tempat-tempat yang dapat berpotensi sebagai tempat perindukan nyamuk dan juga kebersihan lingkungan. Hal tersebut sesuai dengan penelitian Purnama (2012) yang menyatakan adanya hubungan antara status maya index dengan kejadian DBD. Status maya index tinggi memiliki risiko 3,088 kali dibandingkan dengan yang memiliki maya index rendah untuk terkena DBD. Walaupun maya index suatu daerah dalam kategori rendahsedang, tetapi jika masih terdapat kontainer yang positif jentik maka daerah tersebut menjadi potensial terkena DBD.

\section{SIMPULAN}

Status Maya Index Larva Aedes sp. di Kecamatan Sukabumi Kota Bandar Lampung termasuk ke dalam kategori sedang. Kondisi sanitasi lingkungan yang buruk dan keberadaan tempat potensial perkembangbiakan larva banyak ditemukan. Fakta tersebut menggambarkan bahwa penularan DBD di masih perlu diwaspadai.Jenis tempat penampungan air terkontrol yang paling berpotensi sebagai tempat perindukan dan perkembangbiakan dari nyamuk Aedes sp. adalah tempat penampung air pada dispenser dan ember, sedangkan konainer tidak terkontrol yang berpotensi adalah kaleng bekas dan pot bekas. Terdapat 2 jenis larva yang ditemukan pada berbagai tempat penampugan air, yaitu larva Aedes aegypti dengan persentase $73.5 \%$ dan larva Aedesalbopictus dengan persentase $26.5 \%$.

\section{DAFTAR PUSTAKA}

Anies. (2006). Manajemen Berbasis Lingkungan. Jakarta: Gramedia.

Dhewantara, P. W., \& Dinata, A. (2015). Analisis Risiko Dengue Berbasis Maya Index pada Rumah Penderita DBD di Kota Banjar Tahun 2012. Balaba: Jurnal Litbang Pengendalian Penyakit Bersumber Binatang Banjarnegara. https://doi.org/10.22435/balaba.v11 i1.4148.1-8.

Dinkes Kota Bandar Lampung. (2016). Profil kesehatan tahun 2016. Dinas Kesehatan Kota Bandar Lampung.

Dinkes Kota Bandar Lampung. (2019). Profil kesehatan tahun 2019. Dinas Kesehatan Kota Bandar Lampung.

Karnasih, A., \& Winita, R. (2013). Perbandingan Keberadaan Larva Aedes sp. Pada Kontainer Dalam Rumah Antara RW 03 dan RW 07 Kelurahan Cempaka Putih Barat, Jakarta Pusat. Fk UI, 07, 7:17. 
Kemenkes RI. (2016). Infodatin pusat data dan informasi kemeterian kesehatan RI demam berdarah dengue di indonesia. Jakarta.

Kemenkes RI. (2018). Data dan Informasi profil Kesehatan Indonesia 2018.Data Dan Informasi Profil Kesehatan Indonesia.

Prasetyowati, H., \& Ginanjar, A. (2017). Maya Indeks dan Kepadatan Larva Aedes Aegypti di Daerah Endemis DBD Jakarta Timur. Vektora.

Purnama, S. G., \& Baskoro, T. (2012). Maya Index dan Kepadatan Larva Aedes aegypti Terhadap Infeksi Dengue. Makara Kesehatan.

Sari, I. P., Adrial, \& Nofita, E. (2017).Hubungan Kepadatan Larva Aedes spp. dengan Kejadian Demam Berdarah Dengue di Kelurahan Lubuk Buaya Kecamatan Koto Tangah Kota Padang.Jurnal Kesehatan Andalas, 6(1), 41-48. https://doi.org/10.1002/rcm.6902.

Satoto, T.B.T. (2005). Penting Survey Jentik Sebelum Fogging. Jurnal Medika, 31(7), 185.

Soegijanto, S. (2006).Demam Berdarah Dengue Edisi 2.Surabaya: Airlangga University Press.

Sona, B., Rosa, E., \& Kanedi, M. (2019). Maya Index Analysis of Dengue Fever Vector in East Metro SubDistrict Lampung Province Indonesia, 6(1), 1-7.

Supartha, I. W. (2008). Pengendalian Terpadu Vektor Virus Demam Berdarah Dengue, Aedes aegypti (
Linn .) dan Aedes albopictus ( Skuse )( Diptera: Culicidae ). Makalah Disampaikan Dalam Seminar Diesnatalis Universitas Udayana 2008. https://doi.org/10.1016/S00219150(01)00750-X.

Yotopranoto, S., Subekti, S., Rosmanida, \& Salamun. (1998). Analisis dinamika populasivektor pada lokasi dengan kasus demam berdarah dengue yang tinggi di kotamadya surabaya. Majalah Kedokteran Tropis Indonesia,6(12), 23-31. 